\title{
The genus Jania J.V.Lamouroux (Corallinales, Rhodophyta) from Myanmar
}

\begin{abstract}
A taxonomic study on the articulated coralline algae collected from the three coastal zones of Myanmar: Tanintharyi coastal zone, Deltaic coastal zone and Rakhine coastal zone, and lodged in the Herbarium of Department of Marine Science had been carried out based on the morphological, reproductive and anatomical structures. A total of 6 species of the genus, Jania J. V.Lamouroux representing to the tribe Janiae and subfamily Corallinoideae under order Corallinales had been identified as $J$. spectabilis (Harvey ex Grunow) JH Kim, Guiry \& HG Choi, J. ungulata (Yendo) Yendo, J. rubens (Linnaeus) J.V. Lamouroux, J. verrucosa Lamouroux, J. capillacea Harvey and $J$. adhaerens J.V.Lamouroux. J. spectabilis had marginal conceptacles while the remaining five species of Jania possessed axial conceptacles originated in medullary meristems. The detailed descriptions of each species were provided. Moreover, keys for species identification and some distinctive characteristics used as taxonomic criteria were also provided. Furthermore, the distributions of each species along both the coastal zones of Myanmar and the world oceans were presented.
\end{abstract}

Keywords: corallinales, genicula, jania, myanmar, rhodophyta, taxonom
Volume 7 Issue 4 - 2018

\author{
Mya Kyawt Wai \\ Department of Marine Science, Mawlamyine University, \\ Myanmar
}

Correspondence: Mya Kyawt Wai, Lecturer, Department of Marine Science, Mawlamyine University, Myanmar, Email mrakyawtwai@gmail.com

Received: July 17, 2018| Published: August 07, 2018

\section{Introduction}

In division Rhodophyta, coralline algae belong to the family Corallinaceae under the order Corallinales. The coralline algae can be divided into two forms, the articulated (geniculate) corallines and the non-articulated (non-geniculate) corallines. Generally, the plants of the articulated corallines are branched by calcified segments called intergenicula which are separated from one another by unclassified nodes or genicula. Non-geniculate corallines are crustose and may occur on rock, coral skeletons, shells, other algae or seagrasses Many coralline crusts produce knobby protuberances ranging from a millimeter to several centimeters high. The coralline algae are very important in the global carbon cycle, as well as the stability of coral reefs and provide habitat, refuge and grazing areas for numerous fish and invertebrate species.

Corallinaceae was the only one family of the order Corallinales and composed of four subfamilies, namely Metagoniolithoideae, Corallinoideae, Lithophylloideae (Amphiroideae sensu Johansen²) and Mastophoroideae. ${ }^{2,3,4}$ Of these subfamilies, articulated coralline algae were assigned to the Metagoniolithoideae, Lithophylloideae and Corallinoideae. The genus Jania is one of the thirteen genera of subfamily Corallinoideae and also one of the three genera of tribe Janieae (comprising Jania, Haliptilon and Cheilosporum) separated from the tribe Corallineae. ${ }^{5}$ The genus Jania was characterized by having cylindrical intergenicula and branches dichotomous throughout, with marginal and axial conceptacles and comprised 48 species currently accepted taxonomically and distributed throughout the tropical, subtropical, and warm temperate areas. ${ }^{6}$

In Myanmar, Martens ${ }^{7}$ recorded $J$. adhaerens, $J$. fastigiata from Pegu, Diamond I. and South Andaman Is. Kyi Win ${ }^{8}$ listed J. rubens, $J$. nipponica, J. radiata, J. adhaerens and $J$. sp. Moreover, Kyaw Soe and Kyi Win ${ }^{9}$ reported J. rubens, J. nipponica , J. radiata, and Jania $s p$. Soe-Htun ${ }^{10}$ reported the occurrence of J. longiarthra, J. rubens and
Cheilosporum spectabile ( $=$ J. spectabilis) in Rakhine and Tanintharyi coastal zones. Soe-Htun et al., ${ }^{11}$ reported J. radiata from the Gwa coastal zones, Rakhine State. Soe-Htun et al., ${ }^{12}$ accounted the 3 species of Jania such as J. spectabilis, J. pumila and J. radiata along the coastal zones of Myanmar. Mya Kyawt Wai ${ }^{13}$ studied the articulated coralline algae belonging to subfamily Corallinaceae along the coastal zones of Myanmar. She had been identified the 6 species of Jania: $J$. spectabile (=J. spectabilis), J. ungulata, J. rubens, J. verrucosa, $J$. capillacea and $J$. adhaerens. In the present study, species of the genus Jania collected from the coastal zones of Myanmar have been identified as six species of Jania, namely $J$. spectabilis, J. ungulata, $J$. rubens, J. verrucosa, J. capillacea Harvey and J. adhaerens.

The objectives of this study are: 1) to revise the taxonomy of the species of Jania based on the morphology of vegetative and reproductive structures; 2) to know the distribution of each species along the coastal zones of Myanmar and the world oceans.

\section{Materials and methods}

Specimens of articulated coralline algae collected from coastal zones of Myanmar were studied. The collections were dried and preserved in 5\% formaldehyde-seawater and some were prepared for herbarium specimens. These vouchered specimens were deposited in the Herbarium of Department of Marine Science, Mawlamyine University (MMB), Mawlamyine. Moreover, other specimens deposited in the Herbarium of Department of Marine Science, Mawlamyine University, were also studied. Susa fixative $(\mathrm{HgCl}$, $4.5 \mathrm{~g}$; trichloroacetic acid, $2.0 \mathrm{~g}$; glacial acetic acid, $4.0 \mathrm{ml}$; formalin, $20.0 \mathrm{ml}$; water, $76.0 \mathrm{ml}$, after Johansen ${ }^{14}$ ) was used for decalcification of specimens and branches were fixed in that solution for $24 \mathrm{~h}$ and sectioned by razor blade and stained in Ehrlich's hematoxylin. Sectioned specimens were measured under the dissecting and compound microscopes. This taxonomic study followed the classification system of Johansen ${ }^{2}$, Silva and Johansen ${ }^{3}$, Womersely and Johansen ${ }^{15,16}$, Aguirre et al., ${ }^{4}$ Bittner et al., ${ }^{17}$ Guiry ${ }^{18}$. The local 
distributional range of each taxon was arranged from the specimens examined in the Department of Marine Science, Mawlamyine University and worldwide distribution of these algae was also recorded from the literature.

\section{Results}

\section{Classification system of the genus Jania}

Phylum: Rhodophyta

Class: Rhodophyceae

Order: Corallinales Silva \& Johansen

Family: Corallinaceae Lamouroux
Subfamily: Corallinoideae (Areschoug) Foslie

Genus: Jania Lamouroux

Species: J. spectabilis (Harvey ex Grunow) J.H.Kim, Guiry \& H.-G.Choi

J. ungulata (Yendo) Yendo

J. rubens (Linnaeus) J.V.Lamouroux

$J$. verrucosa Lamouroux

J. capillacea Harvey

J. adhaerens J.V.Lamouroux

\section{Key to the species of Jania from Myanmar}

1a. Thalli with marginal conceptacles J. spectabilis

1b. Thalli with axial conceptacles 2

2a. Intergenicula tips compressed, ungulate J. ungulata

2b. Intergenicula tips not compressed. .3

3a. Intergenicula cymoid branched. J. rubens

3b. Intergenicula dichotomous branched .4

4a. Thalli robust, stiff, $7 \mathrm{~cm}$ high J. verrucosa

4b. Thalli capillary, less than $3 \mathrm{~cm}$ high. . .5

5a. Intergenicula $40-100 \mu \mathrm{m}$ in diameter. J. capillacea

5b. Intergenicula $100-200 \mu \mathrm{m}$ in diameter. J. adhaerens

a. Jania spectabilis (Figures 1-11)

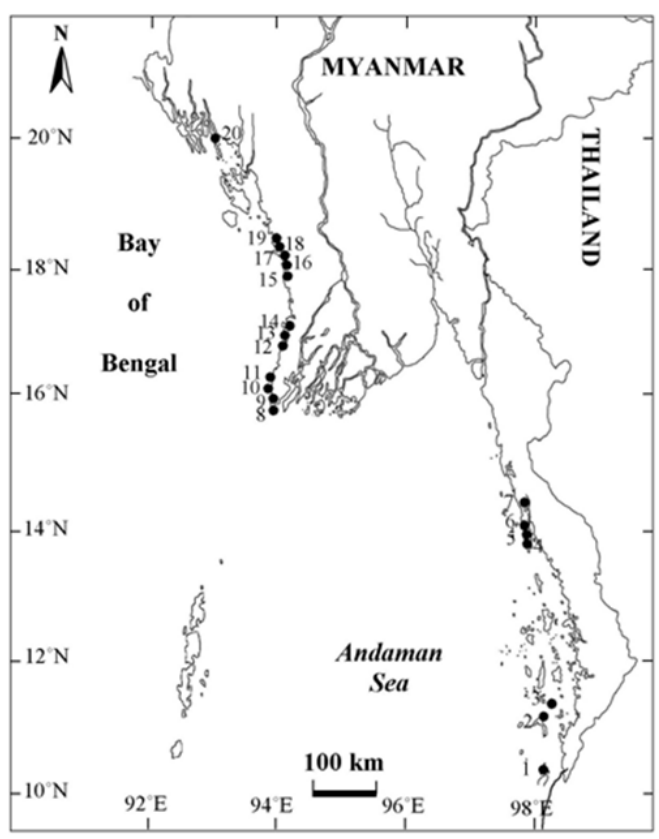

Figure I Map showing the collection sites of species of Jania along the coastal zones of Myanmar. I. St. Luke's I., 2. Lampi I., 3. High I., 4.Wa Maw, 5. Nyaw Byin, 6. Kampani, 7. Mway Taung, 8. Leik I., 9. Mawtin Point, I0. Kyar Kan, II. Pashyu Gyaing, 12. Ngwe Saung, 13. Phoe Kalar I., 14. Makyee, 15. Maw Shwe Gyaing, 16.Sin Phyu Gyaing, 17. Moe Gyo Pyit Gyaing, 18. Ngapali, 19. Mazin, 20. Kyauk La Yaine Gyaing.
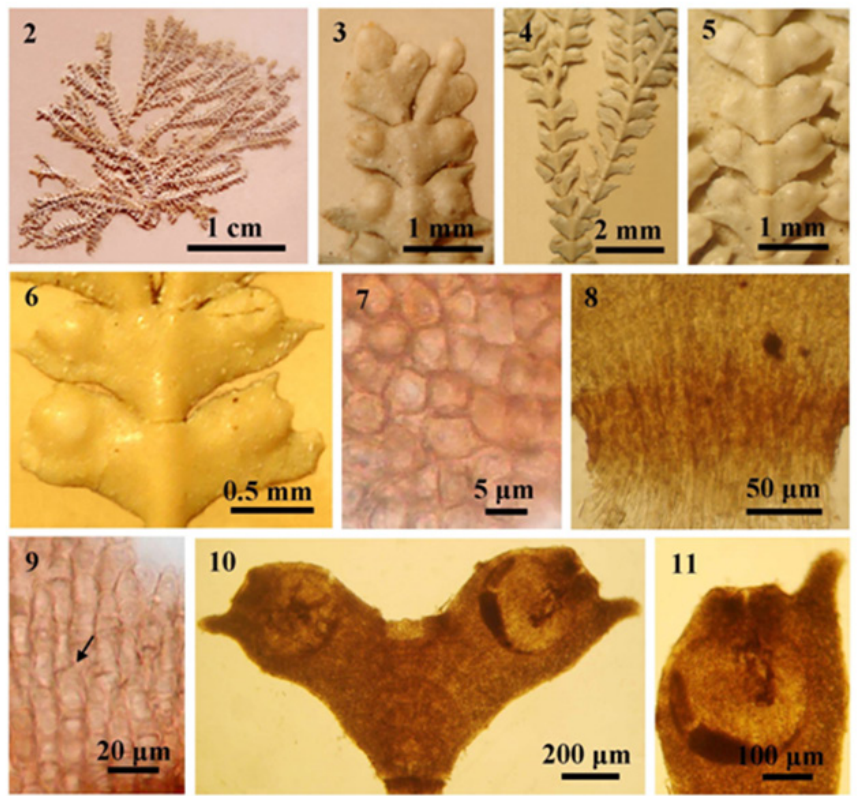

11

Figures 2-II The external and internal structures of Jania spectabilis; (2) Habit; (3) Rounded tip of branches; (4) Thallus showing dichotomous branching; (5-6) Intergenicula with conceptacles formed marginally; (7) Surface view, showing cortical cells; (8) Longitudinal section showing uni-tiered geniculum; (9) Longitudinal section of intergenicula showing lateral fusion among cells (arrow); (I0) Decalcified intergeniculum with conceptacles; (II) Tetrasporangial conceptacle. 


\section{Type locality. Coleva, Tonga ${ }^{6}$}

Description: Thalli forming a clump, pink in color, $1.6-2.2 \mathrm{~cm}$ high, attached to the substratum by a discoid holdfast, composed of wing-like upright intergenicula; intergenicula compressed with prominent midrib; terminal segments acute at the tip; branching regularly dichotomous, lateral branches common at the lower parts; cortical cells ovate, $5-13 \mu \mathrm{m}$ broad in surface view; genicula, 80 $100 \mu \mathrm{m}$ long, $190-200 \mu \mathrm{m}$ in diameter, consisting of 1 tier of medullary cells; compressed intergenicula, $440-550 \mu \mathrm{m}$ long and $0.5-2 \mathrm{~mm}$ in diameter, composed of 5-6 tires of medullary cells, consisting 1-3 layers of cortical cells; interlaced intergenicular filaments forming as equal length tiers, $30-45 \mu \mathrm{m}$ long, $8-10 \mu \mathrm{m}$ in diameter, with lateral fusion; conceptacles embedded at the both sides of intergenicular margin; uniporate tetrasporangial conceptacles $210-470 \mu \mathrm{m}$ in high, $250-300 \mu \mathrm{m}$ in diameter; tetrasporangia $15-20 \mu \mathrm{m}$ long, $10-13 \mu \mathrm{m}$ in diameter. Sexual plants are not encountered in this study.
Ecological notes. Plants grow at the subtidal zone.

Specimens examined. Taninthayi coastal zone: Lampi I. (People's Pearl and Fish Association (PPFC), 27.i.1971; MMB 01041, 01460010461). Deltaic coastal zone: No data. Rakhine coastal zone: No data.

Local distribution: Taninthayi coastal zone: Lampi I.; Deltaic coastal zone: No data; Rakhine coastal zone: No data.

World distribution: Atlantic Ocean- No data; Indian OceanSeychelles, Laccadive Is., India, Sri Lanka, Myanmar (Present study); Indo-Pacific Region- Vietnam, Philippines; Pacific OceanMicronesia, Papua

\section{New Guinea, Solomon Is., Queensland, New Caledonia, Fiji. ${ }^{19}$}

b. Jania ungulata (Figures 12-21)

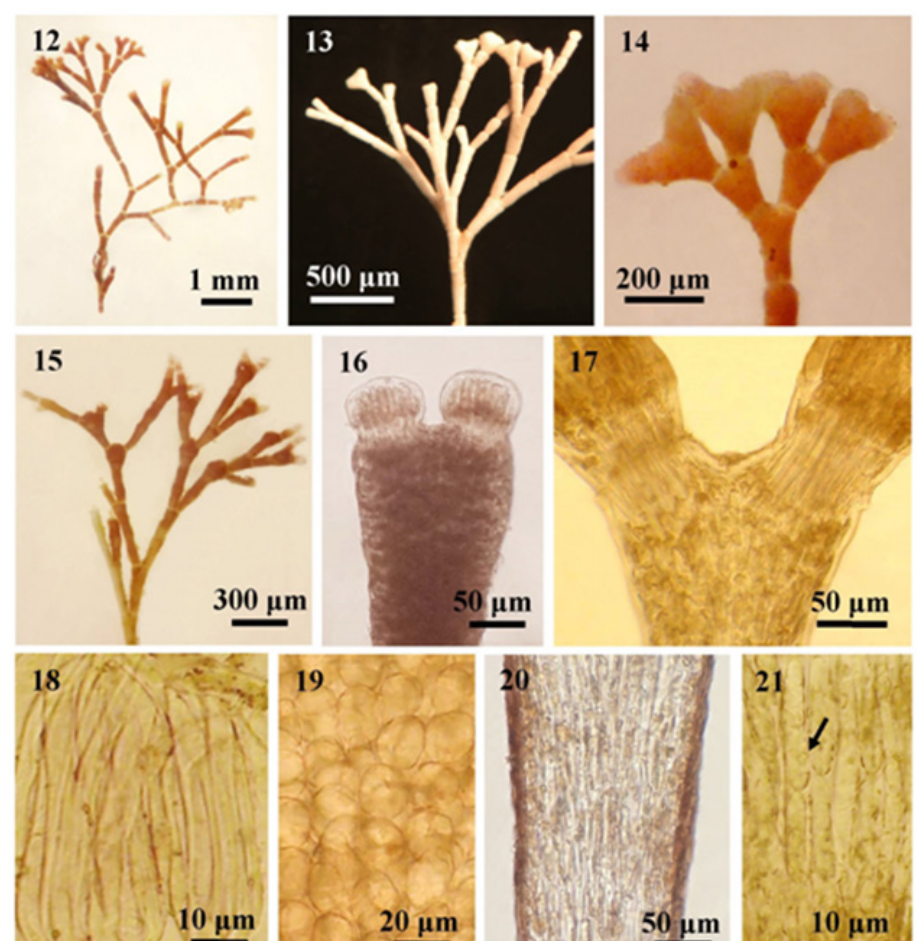

Figures I 2-2I The external and internal structures of Jania ungulate; (I2) Habit; (I3) Thallus showing dichotomous branching; (14) Thallus with compressed or ungulate the terminal segments; (I5) Branches with sporangial conceptacles; (16) Intergeniculum showing apex of an intergeniculum with apical meristems and without cover cells; (17) Genicula forming at dichotomy; (I8) Longitudinal section of genicula showing uni-tiered genicular filaments; (19) Surface view, showing cortical cells; (20-2I) Longitudinal section of intergenicula; (20) Interwoven medullary filaments; (2I) Lateral fusion (arrow) between cells.

\section{Syntype localities: Various, all in Japan. ${ }^{20}$}

Description: Plants erect, pink in colour, $0.5-1 \mathrm{~cm}$ tall, attached to the host plant by a disc-like holdfast; forming in tufts; repeatedly dichotomous, subcomplanate and corymbosely branched, with wide angles of $60-70^{\circ}$; intergenicula cylindrical at the lower and compressed at the upper; the terminal intergenicula broad, and clearly compressed, slightly cordate at the margin; cortical cells ovate, $8-15 \mu \mathrm{m}$ broad in surface view; genicula formed at or above the forks, at the base of each branch and frequently elsewhere as well, $20-50 \mu \mathrm{m}$ in height and $50-100 \mu \mathrm{m}$ in diameter, with 1 tier of medullary cells; intergenicula, cylindrical to compressed, $350-500 \mu \mathrm{m}$ long and $110-260 \mu \mathrm{m}$ in diameter, composed of 4-6 to several tires of medullary cells, consisting 1-2 cortical layer; medullary filaments of the intergenicula, $20-48 \mu \mathrm{m}$ high and $5-13 \mu \mathrm{m}$ in diameter, with lateral fusion; the conceptacles, urn-shaped, formed at the tips of branches, up to $200 \mu \mathrm{m}$ high and $130-160 \mu \mathrm{m}$ in diameter.

Ecological notes. Plants grow on rocks at the middle intertidal zone.

Specimens examined. Tanintharyi coastal zone- Nyaw Byin (Soe-Htun, 11.i.2001; MMB 10419); Kampani(Mya Kyawt Wai, 29.ix.2011; MMB 13092-13094; Aung Aung Htaik, 7.iii.2012; MMB 13095); Mway Taung (Soe-Htun, 5.iv.2001; MMB 10418). Deltaic coastal zone- No data. Rakhine coastal zone- Mawtin Point (SoeHtun, 6.iv.2001; MMB 10416; Mya KyawtWai, 25.ii.2010; MMB 10417); Kyar Kan (Aung Aung Htaik, 17.xi.2009; MMB 10422); Pashyu Gyaing (Mya Kyawt Wai, 16.xi.2009; MMB 13127); Ngwe Saung (Mya Kyawt Wai, 27.ii.2010; MMB 10423); Phoe Kalar I. 
(Mya Kyawt Wai, 5.ii.2012; MMB 13128-13130); Makyee (Mu Mu Aye, 4.x.2006: MMB 10421); Mazin (Mya Kyawt Wai, 2.iv.2007; MMB 10415); Kyauk La Yaine Gyaing (Mya Kyawt Wai, 14.xii.2008; MMB 10414).

Local distribution: Tanintharyi coastal zone- Nyaw Byin, Kampani, Mway Taung; Deltaic coastal zone- No data; Rakhine Coastal RegionMawtin Point, Kyar Kan, Pashyu Gyaing, Ngwe Saung, Phoe Kalar I.,
Makyee, Mazin, Kyauk La Yaine Gyaing.

World distribution: Atlantic Ocean- Costa Rica; Indian OceanSeychelles, Tanzania, Maldives, Bangladesh, Myanmar (Present study); Indo-Pacific Region- Thailand, Vietnam, Philippines; Pacific Ocean- Taiwan, Korea, Japan, Federated States of Micronesia, Papua New Guinea, Queensland, Fiji, Galápagos Islands, Ecuador. ${ }^{21}$

c. Jania rubens (Figures 22-33)

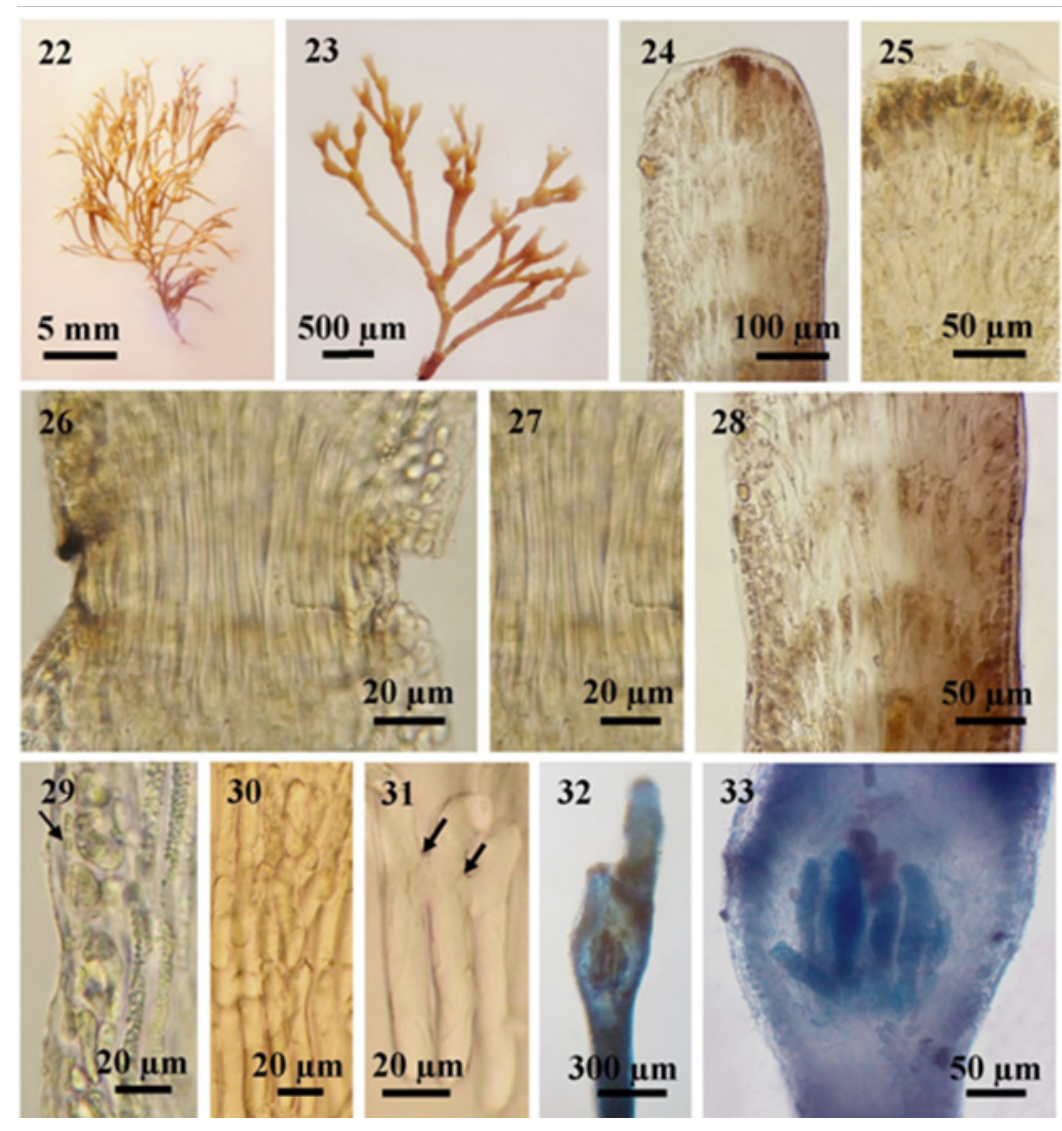

Figures 22-33 The external and internal structures of Jania rubens (Linnaeus) Lamouroux; (22) Habit; (23) Thallus showing dichotomous branching and cymoid clusters of conceptacles; (24) Longitudinal section of intergeniculum; (25) Longitudinal section of intergenicula showing apex of an intergeniculum with apical meristem and without cover cells; (26) Longitudinal section of geniculum; (27) Uni-tiered geniculum; (28) Longitudinal section of intergeniculum showing tiers of medullary cells; (29) Longitudinal section of intergeniculum showing cortex with a single layer of epithallium cells (arrow); (30) Tiers of medullary filaments; (31) Lateral fusions (arrows) among cells; and (32-33) Mature tetrasporangia.

\section{Type locality. Europe. ${ }^{22}$}

Description. Plants erect, densely tufted, sometimes forming extended cushions, rose-red in color, $0.8-1.6 \mathrm{~cm}$ high, $1-1.5 \mathrm{~cm}$ in diameter, attached to the substratum by a minute calcareous disc, consisting of narrow angles, dichotomous and cymoid branches, occasionally four branches formed at a genicula; intergenicula cylindrical and acute or obtuse at tip, $0.7-1.4 \mathrm{~mm}$ in length and 125 $150 \mu \mathrm{m}$ in diameter at the upper; lower intergenicula of the plants somewhat cask-shaped, often about $0.4-1.2 \mathrm{~mm}$ in length and 175 $250 \mu \mathrm{m}$ in diameter; several branches formed at a geniculum and sometimes intervening at the points of branching; cortical cells ovate, $10-15 \mu \mathrm{m}$ broad in surface view; genicula formed at or above the forks, at the base ofeach branch and frequently elsewhere as well, $35-120 \mu \mathrm{m}$ in length and $80-100 \mu \mathrm{m}$ in diameter, with 1 tier of medullary cells; intergenicula branch-bearing segments broadened to $240-300 \mu \mathrm{m}$ diameter at the top; composed of 6-8 tiersof medullary cells, consisting 1-2 cortical layers; medullary filaments of the intergenicula, $43-70 \mu \mathrm{m}$ high and $8-10 \mu \mathrm{m}$ in diameter, with lateral fusion; conceptacles at first terminal, vasiform, and antenniferous, and tend to be borne in chains in a cymoid manner, eventually intercalarly below a fork, with a median protruding ostiole; tetrasporangial conceptacles, $280-360 \mu \mathrm{m}$

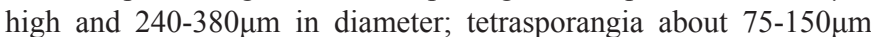
long, $15-30 \mu \mathrm{m}$ in diameter. Sexual plants are not encountered in this study.

Ecological notes. Plants grow on rocks at the middle intertidal zone.

Specimens examined. Tanintharyi coastal zone- Kampani (Aung Aung Htaik, 7.iii.2012; MMB 13104-13105). Deltaic coastal zoneNo data. Rakhine coastal zone- Leik I. (Daw Nyo Nyo Tun, 3.iv.2012; MMB 13146); Mawtin Point (Aung Aung Htaik, 4.vii.2012; MMB 
13101-13103); Kyar Kan (Mya Kyawt Wai, 16.ix.2010; MMB 1309813100).

Local distribution: Tanintharyi coastal zone- Kampani; Deltaic coastal zone- No data; Rakhine coastal zone- Leik I., Mawtin Point, Kyar Kan.

World distribution. Atlantic Ocean- Uruguay, Brazil, Tobago, Lesser Antilles, Venezuela, Caribbean, Jamaica, Belize, Cuba, Florida, North Carolina, Bahamas, Puerto Rico, Barbados, Bermuda, Azores, Ireland, Britain, Norway, Sweden, Netherlands, France, Portugal, Spain, Italy, Adriatic, Greece, Turkey, Israel, Libya, Tunisia, Sardi- nia, Algeria, Balearic Islands, Morocco, Canary Islands, Mauritania, Cape Verde Islands, Senegal, Gambia, Ghana, Nigeria, Cameroon, Ascension; Indian Ocean- South Africa, Réunion, Mauritius, Madagascar, Comoros, Tanzania, Kenya, Somalia, Sudan, Egypt, Israel (Asia), Saudi Arabia, Bahrain, Iran, Pakistan, India, Myanmar ${ }^{9}$ (Present study), Andaman Is.; Indo-Pacific Region- Indonesia, Malaysia, Vietnam, Philippines; Pacific Ocean- Korea, Japan, Marshall Island, Federated States of Micronesia, Solomon Islands, Northern Territory, Queensland, Fiji, Colombia, Chile, California. ${ }^{6}$

d. Jania verrucosa (Figures 34-46)
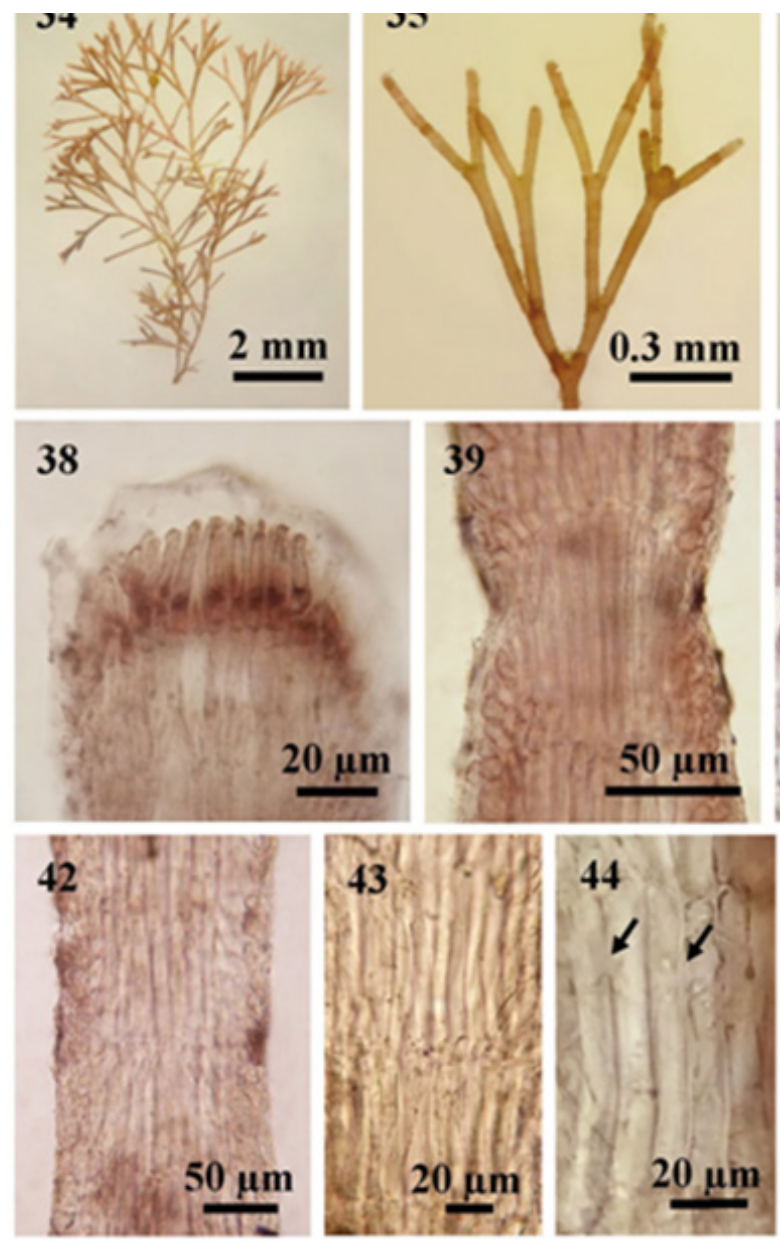
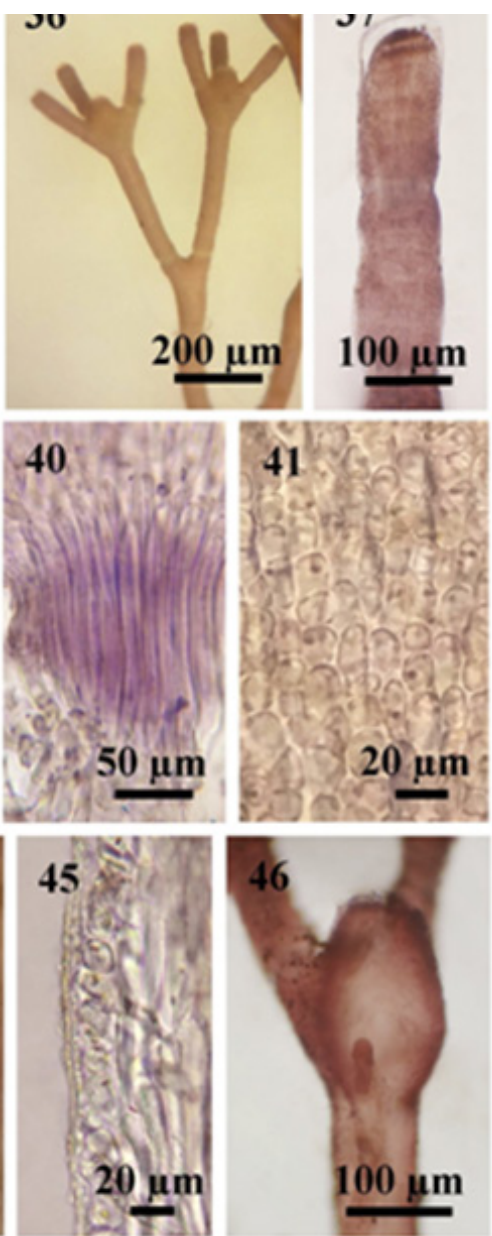

Figures 34-46 The external and internal structures of Jania verrucosa: (34) Habit; (35) Thallus showing dichotomous branching; (36) Intergenicula with conceptacles; (37) Longitudinal section of intergeniculum; (38) Longitudinal section of intergeniculum showing apical cells; (39) Longitudinal section of geniculum; (40) Uni-tiered geniculum; (4I) Surface view, showing cortical cells; (42-45) Longitudinal section of intergenicula: (42-43) Intergeniculum composed of medullary cells; (44) Lateral fusions (arrows) among cells; (45) Mature intergeniculum with two layers of cortical cells; and (46) Longitudinal section of conceptacle.

Type locality. Amérique Méridionale. ${ }^{20}$

Description. Plants erect, forming clumps up to $7 \mathrm{~cm}$ high, and $2 \mathrm{~cm}$ in diameter, dull pink in colour, with stiff and densely tufted branches, growing on the rock by a discoidal holdfast; dichotomous, sometimes corymbosely branched, with narrow angles of $45-60^{\circ}$; intergenicula- terete, shorter at the lower part of the plant, with occasional several adventitious lateral branches at below; tips of branches pale; cortical cells rounded to oblong, $7.5-10 \mu \mathrm{m}$ broad in surface view; genicula formed at the forks, on the intergenicula and at the base of each branch, $40-150 \mu \mathrm{m}$ in length and $50-140 \mu \mathrm{m}$ in diameter, composed of a single tier of medullary cells, $5-10 \mu \mathrm{m}$ in diameter; intergenicula, 
$300-450 \mu \mathrm{m}$ long and more or less uniform in diameter throughout, $120-150 \mu \mathrm{m}$ in diameter at the upper part and $300-370 \mu \mathrm{m}$ long and up to $200 \mu \mathrm{m}$ in diameter at the lower part, composed of interwoven medullary cells forming 6-10 tires, consisting 1-3 layers of cortical cells; medullary filaments of the intergenicula with lateral fusion, $30-70 \mu \mathrm{m}$ in length and $8-10 \mu \mathrm{m}$ in diameter; tetrasporangial conceptacles not abundant, $200-400 \mu \mathrm{m}$ in length and $200-260 \mu \mathrm{m}$ in diameter, forming at the terminal segments, with bi- or tri-antenniferous; mature tetraspores $50-100 \mu \mathrm{m}$ long and $40-90 \mu \mathrm{m}$ broad.

Ecological notes. Plants are epilithic, occurring in shallow pools or on rocks at the middle intertidal zone.

Specimens examined. Tanintharyi coastal zone- No data. Deltaic coastal zone- No data. Rakhine coastal zone- Phoe Kalar I. (Mya Kyawt Wai, 5.ii.2012; MMB 13106-13108); Ngapali (San Tha Tun, 17.iii.1987; MMB 06856); Mazin (Nyan Wai Tun, 30.iv.1984; MMB 02969).

Local distribution. Tanintharyi coastal zone- No data; Deltaic coastal zone- No data; Rakhine coastal zone- Phoe Kalar I., Ngapali, Mazin.

World distribution. Atlantic Ocean- Cape Verde Islands, Mauritania, Sierra Leone, Liberia, Côte d'Ivoire, Ghana Belize, Nigeria, Angola; Indian Ocean- South Africa, Mauritius, Sri Lanka, Myanmar (Present

study); Indo-Pacific Region- Singapore; Pacific Ocean- Queensland, New South Wales, New Zealand, Tasmania, Victoria, South Australia, Western Australia, Hawaiian Islands, Mexico. ${ }^{22}$

e. Jania capillacea (Figures 47-58)
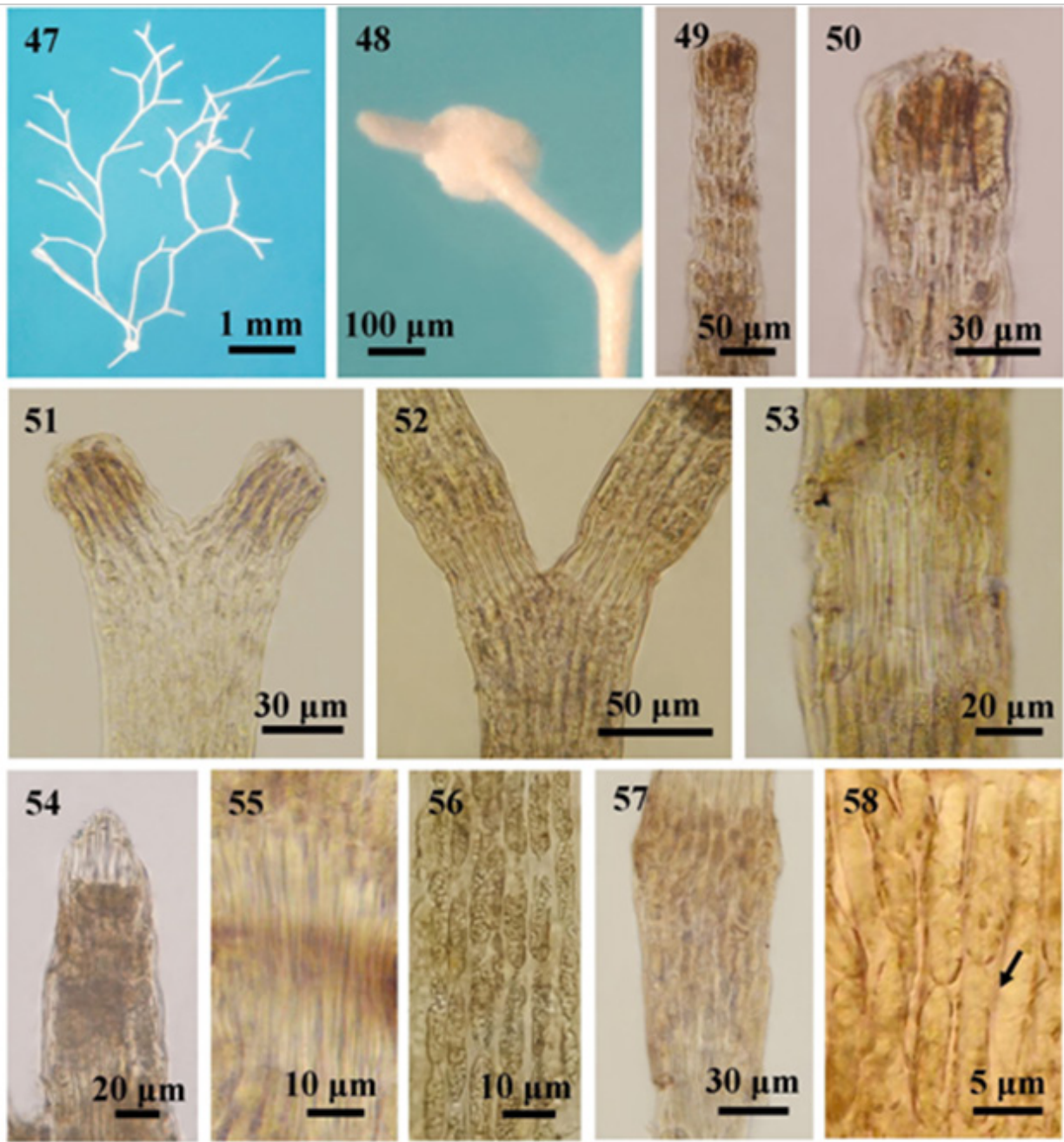

Figures 47-58 The external and internal structures of Jania capillacea; (47) Habit; (48) The accessory attachment discs; (49) Longitudinal sections of intergeniculum; (50) Longitudinal sections of intergeniculum showing apex of an intergeniculum with apical meristem and without cover cells; (5I) A branch with initials of dichotomous; (52) Thallus showing dichotomous branching; (53) Longitudinal section showing uni-tiered geniculum; (54) Geniculum formed at the tip of intergeniculum; (55) Genicular filaments; (56) Surface view, showing cortical cells; (57) Longitudinal section of intergenicula showing tiers of medullary cells; and (58) Lateral fusion (arrow) among cells. 
Type locality. Bahia Honda, Florida, U.S.A.22

Description. Thalli minute, capillary, epiphytic, pink, 5-8mm high, attached to the host plant by a disc-like holdfast; forming in tufts; branching regularly dichotomous with wide angles of $60^{\circ}-100^{\circ}$; the branches sometimes recurved, composed of 1-3 segments or intergenicula between dichotomies; apices blunt; small disc-like attachments often found on branches; cortical cells ovate to obovate, $5-10 \mu \mathrm{m}$ broad in surface view; propagulae with antenna-like branches formed at the upper part of the plants; genicula formed at the fork and along the branches, $20-80 \mu \mathrm{m}$ in height and $40-70 \mu \mathrm{m}$ in diameter, consisting 1 tier of medullar cells; intergenicula, cylindrical, $100-900 \mu \mathrm{m}$ long and $40-100 \mu \mathrm{m}$ in diameter, composed of interwoven medullar cells forming about 10-20 tires, consisting 1-2 cortical layers; medullary filaments of the intergenicula, $28-75 \mu \mathrm{m}$ high and $5-10 \mu \mathrm{m}$ in diameter with lateral fusion; conceptacles were not found; asexual reproduction by attachment discs from any one of the three limbs produced from triangular propagulae.

Ecological notes. Plants are epiphytic on shells and algae at the intertidal zone.

Specimens examined. Tanintharyi coastal zone- St. Luke's I. (Yin Yin Htay, 5.iv.2013; MMB 13137-13139); Lampi I. (Tint Swe, 4.i.2008; MMB 10454); High I. (Yin Yin Htay, 12.xi.2008; MMB 10455); Wa Maw (Yin Yin Htay, 18.iv.2009; MMB 10451); Nyaw Byin (Soe-Htun, 11.i.2002; MMB 10452); Mway Taung (Soe-H- tun, 6.iv.2001; MMB 10453). Deltaic coastal zone- No data. Rakhine coastal zone- Mawtin Point (Soe-Htun, 6.iv.2001; MMB 10447; Mya Kyawt Wai, 25.ii.2010; MMB 10448-10450); Ngwe Saung (Mya Kyawt Wai, 27.ii.2010; MMB 10456); Makyee (Mu Mu Aye, 4.x.2006; MMB 10446); Maw Shwe Gyaing (Soe-Htun, 7.x.2002; MMB 10445); Sin Phyu Gyaing (Soe-Htun, 8.iv.2004; MMB 10444); Moe Gyo Pyit Gyaing (Soe-Htun, 7.iv.2004; MMB 10443); Mazin (Soe-Htun, 4.iv.2004; MMB 10442).

Local distribution. Tanintharyi coastal zone- St. Luke's I., Lampi I., High I., Wa Maw, Nyawbyin, Mway Taung; Deltaic coastal zoneNo data; Rakhine coastal zone- Mawtin Point, Ngwe Saung, Makyee, Maw Shwe Gyaing, Sin Phyu Gyaing, Moe Gyo Pyit Gyaing, Mazin.

World distribution. Atlantic Ocean- Brazil, Lesser Antilles, Caribbean, Panama, Costa Rica, Belize, Jamaica, Cuba, Texas, Florida, North Carolina, Virginia, Bahamas, Hispaniola, Barbados, Virgin Islands, Bermuda, Madeira, Canary Islands, Mauritania, Cape Verde Islands, Ghana, Gabon, Ascension; Indian Ocean- South Africa, Réunion, Mauritius, Seychelles, Tanzania, Kenya, Yemen, Pakistan, India, Laccadive Islands, Maldives; Myanmar (Present study); Indo-Pacific Region- Malaysia, Vietnam, Philippines; Pacific Ocean- Japan, Marshall Island, Federated States of Micronesia, Solomon Islands, Fiji, Islas Revillagigedo, Mexico, Galápagos Islands, Colombia, Ecuador. ${ }^{6}$

f. Jania adhaerens (Figures 59-70)
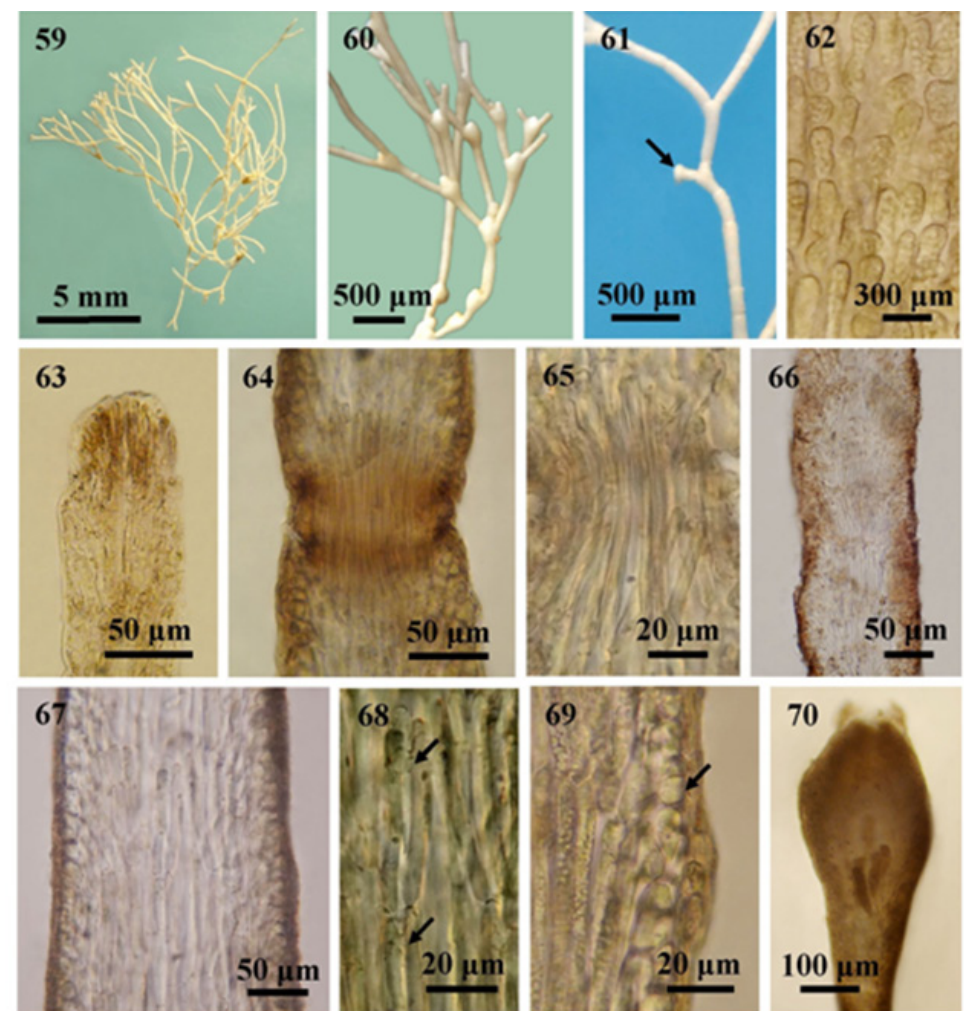

Figures 59-70 The external and internal structures of Jania adhaerens; (59) Habit; (60) A branch with antenniferous axial conceptacles in chain; (6I) The accessory attachment discs (arrow); (62) Surface view, showing cortical cells; (63) Longitudinal sections of intergeniculum showing apex of an intergeniculum with apical meristem and without cover cells; (64) Longitudinal section showing uni- tiered geniculum; (65) Genicular filaments; (66-69) Longitudinal section of intergenicula: (66-67) Intergenicula with several tiers of medullary filaments; (68) Lateral fusions (arrows) among medullary cells; (69) Mature intergeniculum with cortical cells (arrow); and (70) Longitudinal section of mature tetrasporangial conceptacle. 
Type locality. Mediterranean..$^{22}$

Description. Plants erect, capillary, pink in colour, 1-2 cm high, attached to substratum by a disc-like holdfast; forming dense tufts; branching dichotomous with some irregular, wide-angled $\left(30^{\circ}-70^{\circ}\right)$, the lower branches cylindrical, often arcuate; disc-like attachments found on the lower branches; intergenicula bearing branches slightly dilated and retuse at the upper end; apices of branch conical, acute; cortical cells oblong, $5-15 \mu \mathrm{m}$ broad in surface view; genicula formed at the forks and at the base of each branch, $40-50 \mu \mathrm{m}$ in height and $70-100 \mu \mathrm{m}$ in diameter, composed of single tier of medullar cells; intergenicula, cylindrical, short, $100-400 \mu \mathrm{m}$ long and $100-200 \mu \mathrm{m}$ in diameter at the lower part and $100-1500 \mu \mathrm{m}$ long and up to $200 \mu \mathrm{m}$ in diameter at the upper part, composed of interwoven medullary cells forming about 3-6 tiers, 43-70 $\mu \mathrm{m}$ high and 8-10 $\mu \mathrm{m}$ in diameter, consisting 1-3 cortical layers; medullary filaments of the intergenicula with lateral fusion; the conceptacles vasiform, found at or near the ends of the ultimate branches, bearing 2 hornlike projections, which develop into branches and often in time for additional conceptacles; conceptacles, $280-360 \mu \mathrm{m}$ high and $240-380 \mu \mathrm{m}$ in diameter.

Ecological notes. Plants grow as epiphytes on the other algae at the intertidal zone.

Specimens examined. Tanintharyi coastal zone- Kampani (Aung Aung Htike, 7.iii.2012; MMB 13115-13117; 29.iii.2013; MMB 13134-13136). Deltaic coastal zone- No data. Rakhine coastal zone Mawtin Point (Nay Myo Aye, 6.iv.2001; MMB 13112-13113); Ngwe Saung (Mya Kyawt Wai, 24.ii.2012; MMB 13114); Sin Phyu Gyaing
(Soe-Htun, 8.iv.2004; MMB 13109-13111).

Local distribution: Tanintharyi coastal zone- Kampani; Deltaic coastal zone- No data; Rakhine coastal zone- Mawtin Point, Ngwe Saung, Sin Phyu Gyaing.

World distribution. Atlantic Ocean- Brazil, Lesser Antilles, Venezuela, Jamaica, Belize, Cuba, Florida, North Carolina, Bahamas, Puerto Rico, Barbados, Isla Guadalupe, Virgin Islands, Bermuda, Azores, Spain, Balearic Islands, Corsica, Italy, Greece, Israel, Tunisia, Algeria, Morocco, Mauritania, Senegal, Gambia, Sierra Leone, Liberia, Ghana, Cameroon; Indian Ocean- South Africa, Réunion, Mauritius, Madagascar, Seychelles, Tanzania, Kenya, Ethiopia, Egypt, Iran, Pakistan, India, Laccadive Islands, Bangladesh, Myanmar (Present study), Andaman Islands; Indo-Pacific Region- Indonesia, Malaysia, Thailand, Vietnam, Philippines; Pacific Ocean- Taiwan, China, Korea, Japan, Federated States of Micronesia, Papua New Guinea, Queensland, Fiji, Hawaiian Islands, California, Colombia, Ecuador. ${ }^{6}$

\section{Discussion}

In segregating the genera of articulated corallines, the conceptacles position of each genus, the terminal (axial) position of conceptacles in Corallina and Jania and their lateral position in Amphiroa, has been generally used by Decaisne since $1842 .^{2}$ Not only reproductive characters but also vegetative characters such as shape of medullar filaments, type of branching, are important in the classification of articulated coralline algae. Some vegetative structures used in the identification of species are presented in Table 1.

Table I A comparison of species of Jania characterized by distinctive characteristics used as taxonomic criteria

\begin{tabular}{|c|c|c|c|c|c|c|}
\hline & Frond & & Genicula & Intergenicula & & \\
\hline Species & $\begin{array}{l}\text { Maximum } \\
\text { length }\end{array}$ & Habit & $\begin{array}{l}\text { No. of tiers } \\
\text { of medullary } \\
\text { cells }\end{array}$ & Length & Diameter & $\begin{array}{l}\text { Arrangement of medullary } \\
\text { cells }\end{array}$ \\
\hline J. spectabilis & $1.6-2.2 \mathrm{~cm}$ & clump & I tier & $440-550 \mu \mathrm{m}$ & $0.5-2 \mathrm{~mm}$ & $\begin{array}{l}\text { interlaced filaments forming } \\
5-6 \text { tiers of medullary cells }\end{array}$ \\
\hline J. ungulata & $0.5-1 \mathrm{~cm}$ & tufts & I tier & $350-500 \mu \mathrm{m}$ & $110-260 \mu \mathrm{m}$ & $\begin{array}{l}4-6 \text { to several tiers of } \\
\text { medullary cells }\end{array}$ \\
\hline J. rubens & $0.8-1.6 \mathrm{~cm}$ & $\begin{array}{l}\text { erect, densely } \\
\text { tufted }\end{array}$ & I tier & $\begin{array}{l}0.7-1.4 \mathrm{~mm} \text { at the } \\
\text { upper, } 0.4-1.2 \mathrm{~mm} \\
\text { at the lower }\end{array}$ & $\begin{array}{l}125-150 \mu \mathrm{m} \text { at the } \\
\text { upper, } 175-250 \mu \mathrm{m} \text { at } \\
\text { the lower }\end{array}$ & 6-8 tires of medullary cells \\
\hline J. verrucosa & up to $7 \mathrm{~cm}$ & $\begin{array}{l}\text { erect, forming } \\
\text { clumps }\end{array}$ & a single tier & $300-450 \mu \mathrm{m}$ & $120-200 \mu \mathrm{m}$ & 6- 10 tires of medullary cells \\
\hline J. capillacea & $5-8 \mathrm{~mm}$ & epiphytic & I tier & $100-900 \mu \mathrm{m}$ & $40-100 \mu \mathrm{m}$ & $\begin{array}{l}\text { interwoven medullary cells } \\
\text { forming about } 10-20 \text { tiers }\end{array}$ \\
\hline J. adhaerens & $\mathrm{I}-2 \mathrm{~cm}$ & $\begin{array}{l}\text { erect, dense } \\
\text { tufts }\end{array}$ & single tier & $100-1500 \mu \mathrm{m}$ & $100-200 \mu \mathrm{m}$ in diam. & $\begin{array}{l}\text { interwoven medullary cells } \\
\text { forming about 3-6 tiers }\end{array}$ \\
\hline
\end{tabular}


The species identification of articulated coralline algae was carried out based on shape of intergenicula; presence of midrib at the segments; branching type, type of genicula; number of tiers formed at the genicula; shape, composition and arrangement of (short and long) tiers of medullary cells in intergenicula; presence or absence of secondary pit-connections and lateral fusions at medullary filaments of the intergenicula; and position of conceptacles.

Table 2 The distributional range of Jania spp. along the coastal zones of Myanmar

\begin{tabular}{|c|c|c|c|c|c|c|c|}
\hline $\begin{array}{l}\text { Sr. } \\
\text { No. }\end{array}$ & Species & $\begin{array}{l}\text { TCZ } \\
\text { From }\end{array}$ & To & $\begin{array}{l}\text { DCZ } \\
\text { From }\end{array}$ & To & $\begin{array}{l}\text { RCZ } \\
\text { From }\end{array}$ & To \\
\hline I. & J. spectabilis & $\begin{array}{l}\text { Lampi I. } \\
\text { Lat. I0 } \\
58^{\prime} \mathrm{N} \text {, } \\
\text { Long. } \\
98^{\circ} 08^{\prime} \mathrm{E}\end{array}$ & No data & No data & No data & No data & No data \\
\hline 2. & J. ungulata & $\begin{array}{l}\text { Nyaw Byin } \\
\text { Lat. } 13^{\circ} \\
40^{\prime} \mathrm{N} \text {, } \\
\text { Long. } 98^{\circ} 08^{\prime} \mathrm{E}\end{array}$ & $\begin{array}{l}\text { Mway Taung } \\
\text { Lat. I } 4^{\circ} \\
27^{\prime} \mathrm{N}, \\
\text { Long. } 98^{\circ} \\
00^{\prime} \mathrm{E}\end{array}$ & No data & No data & $\begin{array}{l}\text { Mawtin } \\
\text { Point } \\
\text { Lat. } 15^{\circ} \\
57^{\prime} \mathrm{N}, \\
\text { Long. } 94^{\circ} 14^{\prime} \mathrm{E}\end{array}$ & $\begin{array}{l}\text { Kyauk La Yaine Gyaing } \\
\text { Lat. } 19^{\circ} 50^{\prime} \mathrm{N} \text {, Long. } \\
93^{\circ} 25^{\prime} \mathrm{E}\end{array}$ \\
\hline 3. & J. rubens & $\begin{array}{l}\text { Kampani } \\
\text { Lat. } 14^{\circ} \\
02^{\prime} \mathrm{N}, \\
\text { Long. } 98^{\circ} 04^{\prime} \mathrm{E}\end{array}$ & No data & No data & No data & $\begin{array}{l}\text { Leik I. } \\
\text { Lat. I5 } 5 \mathrm{I}^{\prime} \mathrm{N} \text {, Long. } 94^{\circ} 17^{\prime} \mathrm{E}\end{array}$ & $\begin{array}{l}\text { Kyar Kan } \\
\text { Lat. } 15^{\circ} 59^{\prime} \mathrm{N}, \text { Long. } \\
94^{\circ} 13^{\prime} \mathrm{E}\end{array}$ \\
\hline 4. & J. verrucosa & No data & No data & No data & No data & $\begin{array}{l}\text { Phoe Kalar I. Lat. } 16^{\circ} 57^{\prime} \mathrm{N} \text {, } \\
\text { Long. } 94^{\circ} 26^{\prime} \mathrm{E}\end{array}$ & $\begin{array}{l}\text { Mazin } \\
\text { Lat. } 18^{\circ} 26^{\prime} \mathrm{N}, \text { Long. } \\
94^{\circ} 18^{\prime} \mathrm{E}\end{array}$ \\
\hline 5. & J. capillacea & $\begin{array}{l}\text { St. Luke's I. } \\
\text { Lat. I0 } \\
10^{\prime} \mathrm{N}, \\
\text { Long. } 98^{\circ} \\
15^{\prime} \mathrm{E}\end{array}$ & $\begin{array}{l}\text { Mway Taung } \\
\text { Lat. I } 4^{\circ} \\
27^{\prime} \mathrm{N}, \\
\text { Long. } 98^{\circ} \\
00^{\prime} \mathrm{E}\end{array}$ & No data & No data & $\begin{array}{l}\text { Mawtin } \\
\text { Point } \\
\text { Lat. I5 } \\
57^{\prime} \mathrm{N}, \\
\text { Long. } 94^{\circ} 14^{\prime} \mathrm{E}\end{array}$ & $\begin{array}{l}\text { Mazin } \\
\text { Lat. } 18^{\circ} \\
26^{\prime} \mathrm{N} \text {, Long. } 94^{\circ} \\
18^{\prime} \mathrm{E}\end{array}$ \\
\hline 6. & J. adhaerens & $\begin{array}{l}\text { Kampani } \\
\text { Lat. } 14^{\circ} \\
02^{\prime} \mathrm{N}, \\
\text { Long. } 98^{\circ} 04^{\prime} \mathrm{E}\end{array}$ & No data & No data & No data & $\begin{array}{l}\text { Mawtin } \\
\text { Point } \\
\text { Lat. } 15^{\circ} 57^{\prime} \mathrm{N} \text {, Long. } 94^{\circ} 14^{\prime} \mathrm{E}\end{array}$ & $\begin{array}{l}\text { Sin Phyu Gyaing } \\
\text { Lat. } 18^{\circ} \\
\text { I4' N, } \\
\text { Long. } 94^{\circ} 20^{\prime} \mathrm{E}\end{array}$ \\
\hline
\end{tabular}

Abbreviations: TCZ, The Taninthayi coastal zone; DCZ, The deltaic coastal zone; RCZ, The Rakhine coastal zone.

J. spectabilis was firstly described as Cheilosporum spectabile by Harvey ex Grunow in $1874 .{ }^{20}$ Based on nuclear SSU rDNA sequences and anatomical data, some species of the genera Cheilosporum, Haliptilon, and Jania had been combined into a single genus, Jania including Cheilosporum spectabile Harvey ex Grunow by Kim et al., ${ }^{23}$ So, Jania spectabilis (Harvey ex Grunow) Kim, Guiry \& Choi is currently accepted name of Cheilosporum spectabile Harvey ex Grunow. Generally, J. spectabilis can be distinguished by dichotomous branching, flattened and wing-like intergenicula with prominent midrib and marginal conceptacles embedded on the both sides of wings. The morphology of this species differs from $J$. cultrata and J. sagittata in position of conceptacles, tip of branches and shape of intergenicula. The two conceptacles form on each side of intergeniculum in $J$. cultrata whereas only one conceptacle occurs on each side of intergeniculum in $J$. spectabilis. ${ }^{24}$ In addition, intergenicular lengths of $J$. sagittata $(435-665(-750) \mu \mathrm{m})$ are longer than those of $J$. spectabilis $(440-550 \mu \mathrm{m}){ }^{24}$ Moreover, both sides of integenicula found in $J$. sagittata are more sagittate than those of $J$. spectabilis.

$J$ spectiblis of the Samoa showed dichotomous branches commonly found from the mid to the upper parts and adventitious branches were found at the lower parts..$^{25}$ The tip of the trilobe segments were rounded in Samoa species. Species of Myanmar agree well with those species in having branching dichotomous and adventitious branches and differ from those species in having acute tip. Jha et al. ${ }^{26}$ also reported that $J$. spectiblis from India were markedly flattened with prominent midrib and wings on both sides. The solitary or paired conceptacles and acute tip of segments were found in Indian species. Acute tip can also be found at the intergenicula in the species of Myanmar but solitary conceptacles cannot be observed. In Myanmar, Soe-Htun ${ }^{10}$ firstly reported $J$. spectabilis (as Cheilosporum spectabile) from Rakhine coastal zone. Soe-Htun et al., ${ }^{12}$ accounted $J$. spectabilis from Tanintharyi coastal zone. In present study, this species is recorded only from Lampi I. (Lat. $10^{\circ} 58^{\prime} \mathrm{N}$, Long. $98^{\circ} 08^{\prime} \mathrm{E}$ ) according to herbaria housed in Marine Science Department, Mawlamyine University. It is distributed throughout the tropical Regions of the Pacific Ocean, Indian Ocean, and Indo-Pacific Region.

J. ungulata can be distinguished from other species by the compressed and ungulate tip of segments and subcomplanate and closely corymbose branching at the upper part of plant. In 1902, Yendo described Jania ungulata and J. ungulata f. brevior as new species of the genus Corallina from Japan. According to his description of these species, the habit of $J$. ungulata was similar to the habit of Corallina adhaerens in forming a large mass of spongy network. J. ungulata 
was smaller than $J$. ungulata f. brevior in virtue of the shortness of the articuli. He did not give distinguished characters between the two species. So, Taylor ${ }^{27}$ suggested that his specimens from Galapago's Is. could be f. brevior Yendo but he described it as J. ungulata because Yendo did not give measurements of his plants.

In this study, $J$. ungulata has been recorded from Nyaw Byin (Lat. $13^{\circ} 40^{\prime} \mathrm{N}$, Long. $98^{\circ} 06^{\prime} \mathrm{E}$ ) to Mway Taung (Lat. $14^{\circ} 27^{\prime} \mathrm{N}$, Long. $98^{\circ} 00^{\prime} \mathrm{E}$ ) along the Tanintharyi coastal zone and Mawtin Point (Lat. $15^{\circ} 57^{\prime} \mathrm{N}$, Long. $94^{\circ} 14^{\prime} \mathrm{E}$ ) to Kyauk La Yaine Gyaing (Lat. $19^{\circ} 50^{\prime} \mathrm{N}$, Long. $93^{\circ} 25^{\prime} \mathrm{E}$ ) along the Rakhine coastal zone based from specimens examined. $J$. ungulata is distributed in tropical and subtropical areas of all of the oceans.

In $1758 \mathrm{~J}$. rubens was firstly described as Corallina rubens by Linnaeus because of having dichotomous branched and cylindrical intergenicula with broader upper ends. ${ }^{28}$ Lamouroux ${ }^{29}$ proposed the genus Jania and firstly mentioned Jania rubens which was regarded as a lectotype species of the genus Jania. According to description of Lamouroux, J. rubens has dichotomous intergenicula which are cylindrical and club-shaped; terminal conceptacles are solitary or connected as if strung with one or two appendages.

In the present study, $J$. rubens can be recognized by its erect and corymbose branches, club-shaped terminal branches, and cymoid clusters of conceptacles. The branches of $J$. rubens are cylindrical at the upper and ultimate branches are club-shaped where as lower branches are subcylidrical to cask-shaped. The branching type of this species is dichotomous forming cymoid manner. Sometimes, several branches formed at a geniculum and sometimes intervening at the points of branching but some branches formed along the intergenicula. Likewise, Taylor (1967) described several segments of this species intervening at the points of branching. He also described the corymbose type of branching in this species. In 1945, Taylor suggested the similar habits of $J$. mexicana and $J$. rubens but the proportion and diameters of the intergenicula are different and intergenicula of $J$. mexicana was much more slender than that of J. rubens. In Myanmar, Kyaw Soe and Kyi Win ${ }^{9}$ firstly described $J$. rubens from Rakhine and Tanintharyi coastal zones. This species are growing epilithically on the rocks at mid intertidal region along the Kampani (Lat $14^{\circ} 02^{\prime} \mathrm{N}$, Long $98^{\circ} 04^{\prime}$ E) along the Tanintharyi coastal zone and Leik I. (Lat. $15^{\circ} 51^{\prime} \mathrm{N}$, Long. $94^{\circ} 17^{\prime} \mathrm{E}$ ) to Kyar Kan (Lat. $15^{\circ} 59^{\prime} \mathrm{N}$, Long. $94^{\circ} 13^{\prime} \mathrm{E}$ ) along the Rakhine coastal zone. J. rubens is distributed throughout the tropical and subtropical areas of all of the oceans.

Although Lamouroux ${ }^{29}$ firstly described $J$. verrucosa, $J$. pedunculata and $J$. crassa were also firstly described in $1821,{ }^{30}$ the latter two are currently recorded as synonyms of the former. Kützing ${ }^{31}$ identified $J$. verrucosa under the name of Corallina natalensis, and C. pedunculata and illustrated the habit, warty intergenicula and branching pattern of these species. It was found that $J$. pedunculata had a branch with 8-11 tiers of medullary cells per intergeniculum in his illustrations. In this study, the original nomenclature by Lamaoroux is retained.

Dawson $^{32}$ identified specimens of $J$. verrucosa from Mexico as $J$. natalensis and discussed that this species was similar with J. mexicana in habit but $J$. verrucosa was distinctly larger in all respects and had irregularly elongate intergenicula. Tseng ${ }^{30}$ identified this species from China as $J$. crassa and he described that plants from China are dull grey-pink in colour and turfted on rocks. Intergenicula of those plants are cylindrical and dichotomous, with several adventitious branchlets. Likewise, the plants of Myanmar are dull pink in colour and are composed of stiff and densely tufted branches. Dichotomous branchings with narrow angle are observed throughout the plants. Tips of the intergenicula are pale in colour. The several adventitious lateral branches are occasionally observed at below the intergenicula.

The thalli of $J$. verrucosa are more robust than that of the other species of Jania observed in Myanmar. Medullary cells of the intergenicula and genicula are larger than those of the other species of Jania in the present study. The warty like epiphytic plants are mostly found on the middle and lower part of intergenicula. Axial conceptacles with two-three antennae occur on the terminal part of the branches. This species can found epilithically growing on the rocks and in shallow tide pools at the mid intertidal zone of Phoekalar Is., Chaungtha coastal areas.

Womersley and Johansen ${ }^{15}$ also described that $J$. verrucosa from Southern Australia was light to medium red-brown, fading to greywhite in colour and the branches were densely tufted and fastigiated. Farr et al., ${ }^{1}$ also described the two other names which had been used for $J$. verrucosa in New Zealand, namely $J$. crassa and $J$. novaezelandiae. Pale tip are observed in New Zealand's species as well as species of Myanmar. Rosas-Alquicira et al., ${ }^{33}$ reported that the current name of both $J$. crassa and $J$. natalensis was $J$. verrucosa but they proposed that taxonomic status of these species were needed to be confirmed by comparirive studies of both types. This species are scarcely growing on the rocks at mid intertidal region of Phoe Kalar I. (Lat. $16^{\circ} 57^{\prime} \mathrm{N}$, Long. $94^{\circ} 26^{\prime} \mathrm{E}$ ) and Mazin (Lat. $18^{\circ} 26^{\prime} \mathrm{N}$, Long. $94^{\circ} 18^{\prime} \mathrm{E}$ ) at the Rakhine coastal zone. Jania verrucosa is distributed throughout the tropical and subtropical areas of all of the oceans.

The attachments discs can be found at the basal part in both $J$. capillace $a$ and J. adhaerens. However, the former can be distinguished from the latter by smaller diameter of segments $(40-100 \mu \mathrm{m})$ and presence of triangular propagulae at the upper part of plant. Dawson ${ }^{32}$ described that propagulae formed at the upper part of the plant has antenna-like branches at the upper corners. Attachment discs occur on one of those branches and regenerate a new plant from discs. Rosas-Alquicira et al., ${ }^{33}$ discussed that $J$. capillaceae was regarded as current name but status and disposition of this species was uncertain because the type was not studied in a modern context. J. capillacea is distributed from St. Luke's I. (Lat. $10^{\circ} 10^{\prime} \mathrm{N}$, Long. $98^{\circ} 15^{\prime} \mathrm{E}$ ) to Mway Taung (Lat. $14^{\circ} 27^{\prime} \mathrm{N}$, Long. $98^{\circ} 00^{\prime} \mathrm{E}$ ) along the Tanintharyi coastal zones and, Mawtin Point (Lat. $15^{\circ} 57^{\prime}$ N, Long. $94^{\circ} 14^{\prime} \mathrm{E}$ ) to Mazin (Lat. $18^{\circ} 26^{\prime} \mathrm{N}$, Long. $94^{\circ} 18^{\prime} \mathrm{E}$ ) along the Rakhine coastal zones of Myanmar, except the deltaic coastal zone. It is widely distributed throughout the tropical and subtropical Regions of the Atlantic, Indian and Pacific Oceans, and Indo-Pacific Region.

Yendo $^{34}$ described $J$. adhaerens from Japan such as slender capillary intergenicula, irregularly decussate dichotomous branches with slightly attenuated at ultimate and formed fastening discs at their ends. He discussed that many species of Jania e.g. Jania capillacea, $J$. micrarthrodia $f$. antennina, $J$. micrarthrodia $f$. tennissima, $J$. tenella, J. norae-zelandae and $J$. ungulata, were closely related to $J$. adhaerens from the warmer part of the Atlantic and the Pacific Ocean. He pointed out that the relative size of the intergenicula was essential for distinguishing character. In 1953, Dawson discussed that the description of $J$. adhaerens given by Yendo was similar or equal to $J$. decussato-dichotoma and to several other species. He also discussed that identification of Jania decussato-dichotoma and other species may be confused with $J$. adhaerens because of absence of an adequate 
description, a type specimen, an authentic illustration and the source of the original material of the latter species. Haung ${ }^{35}$ reported that the species $J$. decussato-dichotoma (Yendo) Yendo was synonym of $J$. adhaerens. Hoek et al., ${ }^{36}$ described rounded attachment discs present at the creeping basal part of thalli in this species. Likewise, Coppejans et al., ${ }^{37}$ aslo decribed this species of Sri Lanka as secondary adhesion discs present on the cylindrical intergenicula. In present study, accessory attachments discs can also be observed especially at the basal part of thallus. Rosas-Alquicira et al., ${ }^{33}$ described that the status of this species was currently accepted but it was uncertain because the type was not studied in a mordern context. In Myanmar, Martens ${ }^{7}$ firstly reported J. adhaerens from South Andaman Is. Kyi$\mathrm{Win}^{8}$ and Kyaw Soe and Kyi Win ${ }^{9}$ identified the J. adhaerens from Tanintharyi coastal zone. In present study, J. adhaerens occurs along the Tanintharyi and Rakhine coastal zones of Myanmar from Kampani (Lat. $14^{\circ} 02^{\prime} \mathrm{N}$, Long. $98^{\circ} 04^{\prime} \mathrm{E}$ ) in the south to Sin Phyu Gyaing (Lat. $18^{\circ} 14^{\prime} \mathrm{N}$, Long. $94^{\circ} 20^{\prime} \mathrm{E}$ ) in the north. The wide phytogeographic distribution was observed throughout the tropics to subtropics.

\section{Conclusion}

Research on the systematics of the articulated corallinaceae belonging to subfamily Corallinoideae was conducted in the present study. Firstly, the taxonomic study of articulated coralline algae collected from the coastal zones of Myanamr was described. Detailed descriptions of six species of the genus, Jania were provided. The species were $J$. spectabilis, J. ungulata, J. rubens, J. verrucosa, J. capillacea Harvey and $J$. adhaerens. Moreover, the distributions of each species along the coastal zones of Myanmar and world were studied based on the imformation from specimens examined and available literature. J. spectabilis distributes only along the Tanintharyi coastal zones while the other five species distribute along the Rakhine and Tanintharyi coastal zones. J. spectabilis are distributed throughout the tropical and subtropical oceans except the Atlantic Ocean. J. ungulata, J. rubens, J. verrucosa, J. capillacea and $J$. adhaerens are widely distributed throughout the tropical and subtropical Regions of the Atlantic, Indian and Pacific Oceans, and Indo-Pacific Regions.

Moreover, an assemblage of calcified articulated coralline algae provides as habitats for invertebrates and nursery grounds for fish larvae. So, it also serves for the maintenance of biodiversity. Consequently, coralline algae contribute in the formation of coral reef because they precipitate calcium carbonate as calcite. In addition, coralline algae are one of the components of coral reef ecosystem. Therefore, research works on these algae are still needed to be worked out the confirmation of systematics positions and developmental processes pertaining to the reef formation in nature as of sustainable marine resource management.

\section{Acknowledgements}

I wish to express my sincere thanks to Dr. Aung Myat Kyaw Sein, Rector of Mawlamyine University, Dr. Mie Mie Sein and Dr. San San Aye, Pro-Rectors of Mawlamyine University for their permission to carry out this research work. I would like to express my gratitude to Dr. San Tha Tun, Professor and Head of Department of Marine Science, Mawlamyine University, for his valuable guidance and for providing the departmental facilities. Thanks are due to U Soe-Htun, Professor and Head (Retired), Department of Marine Science, for his guidance during this research work. Thanks are also due to all my respected teachers and colleagues for their encouragement. Finally, my infinite thanks are attributive to my beloved parents for their kind support made to reach the goal of this work.

\section{Conflict of Interest}

None.

\section{References}

1. Farr T, Broom J, Hart D, et al. Common coralline algae of northern New Zealand. An identification guide. NIWA Information Series. 2009;(70):1125.

2. Johansen HW. Morphology and systematics of coralline algae with special reference to Calliathron. University of California Publications in Botany. 1969;49: 78 p.

3. Silva HW, Johansen HW. A reappraisal of the order Corallinales (Rhodophyceae). Br Phycol J. 1986;21(3):245-254.

4. Aguirre J, Perfectti F, Braga JC. Integrating phylogeny, molecular clocks, and the fossil record in the evolution of coralline algae (Corallinales and Sporolithales, Rhodophyta). Paleobiology. 2010;36(4):519-533.

5. Johansen HW, Silva PC. Janieae and Lithotricheae: two new tribes of articulated Corallinaceae (Rhodophyta). Phycologia. 1978;17(4):413-417.

6. Guiry MD, Guiry GM. Algae Base. World-wide electronic publication, National University of Ireland, Galway. 2017.

7. Martens GV. List of algae collected by Mr. S. Kutz in Burma and adjacent islands. Stallyardt. 1871;461-469.

8. Kyi Win. A classified list of the seaweeds of Burma. Proceedings of the Burma Research Congress. 1972;25-29.

9. Kyaw-Soe, Kyi-Win. Seaweeds for utilization. University Translation and Publication Department. Publication. 1977;2(168): 502 (in Myanmar).

10. Soe-Htun U. The Seaweed Resources of Myanmar. In: Critchley AT, Ohno M, editors. Seaweed resources of the world. Kanakawa International Fisheries Training Center, Japan International Cooperation Agency (JICA): 1998; pp. 99-105.

11. Soe-Htun, Mya Kyawt Wai, Thida Nyunt, et al. Notes on some marine benthic red algae of Gwa Coastal Areas I. Rhodophyta (Goniotrichales, Stylonematales, Erythropeltidales, Bangiales, Acrochaetiales, Nemaliales, Corallinales, Gelidiales and Halymeniales. Jour. Myan. Acad. Arts \& Sc. 2009;7(5):115-142.

12. Soe-Htun, Mya Kyawt Wai, Thida Nyunt, et al. Checklist, distribution and potential utilization of marine algae of Myanmar II. Rhodophyta (Red algae). Jour Myan Acad Arts \& Sc. 2009;7(5):279-305.

13. Mya Kyawt Wai. Systematics of the Articulated Corallinaceae (Corallinales, Rhodophyta) of Myanmar. Unpublished PhD Thesis. Department of Marine science, University of Mawlamyine. 2013. 246 p.

14. Johansen HW. Reproduction of the articulated coralline Amphiroa ephedraea. J. Phycol. 1968;4:319-328.

15. Womersley HBS, Johansen HW. Subfamily Amphiroideae Johansen. In: Womersley HBS, editors. The marine benthic flora of Southern Australia. Rhodophyta. Part IIIB. Commonwealth of Australia, Union Offset, Canberra. 1996; p. 283-288.

16. Womersley HBS, Johansen HW. Subfamily Corallinoideae (Areschoug) Foslie. In: Womersley HBS, editors. The marine benthic flora of Southern Australia. Rhodophyta. Part IIIB. Commonwealth of Australia, Union Offset, Canberra. 1996; p. 288-317.

17. Bittner L, Payri CE, Maneveldt GW, et al. Evolutionary history of the Corallinales (Corallinophycidae, Rhodophyta) inferred from nuclear, plastidial and mitochondrial genomes. Molecular Phylogenetics and Evolution. 2011;61(3):697-713. 
18. Guiry MD, Guiry GM. Algae Base. World-wide electronic publication, National University of Ireland, Galway. 2009.

19. Guiry MD, Guiry GM. Algae Base. World-wide electronic publication, National University of Ireland, Galway. 2012.

20. Silva PC, Basson PW, Moe RL. Catalogue of the benthic marine algae of the Indian Ocean. University of California Publications in Botany. 1996; 79: $1259 \mathrm{p}$.

21. Guiry MD, Guiry GM. Algae Base. World-wide electronic publication, National University of Ireland, Galway. 2016.

22. Guiry MD, Guiry GM. 2013. Algae Base. World-wide electronic publication, National University of Ireland, Galway. 2013.

23. Kim JH, Guiry MD, Oak JH, et al. Phylogenetic relationships within the tribe Janieae (Corallinales, Rhodophyta) based on molecular and morphological data: A reappraisal of Jania. J. Phycol. 2007;43:1310-1319.

24. Moura CWN, Guimarães SMPB. O gênero Cheilosporum (Decaisne) Zanardini (Corallinales, Rhodophyta) no litoral do Brasil. Revista Brasil. Bot. 2002;25(1):65-77.

25. Skelton PA. Seaweeds of American Samoa. Department of Marine \& Wildlife Resources, Government of American Samoa. 2003; 103 p.

26. Jha B, Reddy CRK, Thakur MC. Seaweeds of India. The Diversity and Distribution of Seaweeds of the Gujarat Coast. 2009; 215 p.

27. Taylor WR. Pacific marine algae of the Allan Hancock expeditions to the Galapagos Islands. Allan Hancock Pacific Expeditions. 1945;12:528 p.
28. Manza AV. A revision of the genera of articulated corallines. The Philippines Journal of Science. 1940;71(3):239-316.

29. Lamouroux JVF. Histoire des Polypiers Coralligenes Flexibles. 1816; 558

30. Tseng CK. Common seaweeds of China. Science Press, Beijing.1983; 316 p.

31. Kutzing FT. Tabulae phycologicae. 1858; Volume VIII, ii +48 pages, 100 plates. Nordhausen.

32. Dawson EY. Marine red algae of Pacific Mexico. Part I. Bangiales to Corallinaceae subf. Corallinoideae. Allan Hancock Pac Exped 1953;17:238

33. Rosas Alquicira EF, Riosmena Rodríguez R, Afonso Carrillo J. Taxonomic biodiversity of geniculate coralline red algae (Corallinales, Rhodophyta) from the Macaronesian region: summary and analysis. Helgol Mar Res. 2011;65(2):133-153

34. Yendo K. Corallinae verae Japonicae. J Coll Sc. Imp Univ Tokyo 1902; 16(3):1-36.

35. Haung SF. Marine algae of Kuei-Shan Dao, Taiwan. Taiwania. 1999;44(1): $49-71$.

36. Hoek C, van den, Mann DG, Jahns HM. Algae. An introduction to phycology. Cambridge University Press. 1995;1-101.

37. Coppejans E, Leliaert F, Dargent O, et al. Sri Lankan seaweeds. Methodologies and field guide to the dominant species. 2009;6:265. 